\title{
Identification of malignant pleural mesothelioma in 19-years old male patient
}

\begin{abstract}
Mesothelioma is a tumor that derives from the mesodermic surface of the celomic embryonic cavity. Since the $50^{\text {th }}$ decade of in the last century the association of this tumor is known with the asbestos. Nevertheless, the appearance in young patients without exposure to this substance they have been described. Although it is not very frequent in the medical practice. The case that we present of a 19 years old male who went for thoracic pain, dyspnea on effort and loss of weight of 6 months of evolution. An epithelioid mesothelioma with papillary areas was histologically diagnosed. Their evolution isn't modified by the treatment at all with Carboplatino, Paclitaxel and Vinblastina.
\end{abstract}

Keywords: mesothelioma, asbestos, mesodermic surface
Volume 6 Issue | - 2019

Yuslier Miró Jiménez

Educational Hospital Iván Portuondo, Cuba

Correspondence: Yuslier Miró Jiménez, Professor of Interna Medicine, Educational Hospital Iván Portuondo, University of Medical Science Artemisa, 122A between 29 and 31 \# 2922. Marianao, La Habana, Cuba, Tel +5352610547,

Email yusliermiro@nauta.cu

Received: November 26, 2018 | Published: January 03, 2019

\section{Introduction}

Mesothelioma is a tumor that derives from the mesodermic surface of the celomic embryonic cavity that later on will give place to the pleura, pericardium, peritoneum and the vaginalis tunic of the testicle. This mesodermic origin it confers the potentiality to developing an epithelioid component and other sarcomatous. ${ }^{1}$ It is calculated that the risk of suffering pleural illness secondary to this exposure is of $8 \%-13 \% .^{2}$ The pleural mesothelioma (PM) is classified in three histopathological types: epithelial (55-65\%), sarcomatous (10-15\%) and mixed or two-phase (20-35\%). The first one has better presage and pathologically it is very similar to the adenocarcinoma, the second one is similar to a true sarcoma and the last one presents the epithelial component and sarcomatous. ${ }^{3}$ More than 3000 new cases are diagnosed annually in United States. ${ }^{4}$ In Europe the incidence is considered in 20 cases for million a year and also will foresee a global increase of the cases. ${ }^{5}$ It is an illness to male adults (70-80\% of the cases). Although they have been published exceptional cases in children. ${ }^{6-8}$ It is a strange tumor, with increase of their incidence with the professional exposure to the asbestos., ${ }^{910}$ This case is presented to be a young person without occupational exposure or previous toxic habits.

\section{Case presentation}

A 19-years- old male, with apparent personal antecedents of health, who denies smoking habits. It began 6 months ago with a pungent thoracic pain, intermittent to the beginning that later became constant, toward the base of the right side, with previous irradiation toward the breastbone and the homolateral flank, of moderate intensity (4-5 in pain scale of 10) that initially alleviated with non-steroidal antinflamatories. It was interpreted and treated in their Health Area like a somatic pain during the first three months of the beginning of the symptoms. Appears later on night sweat without fever that wet the clothes, anorexy, discreet loss of weigh not quantifiable for the patient and dyspnea of moderate efforts as to walk more than 5 blocks and to go up stairways, all this associated to worsening of the pain. The patient was transferred to our institution and him was study following the institutional protocol of prolonged thoracic pain by common consent with the patient and his family (Table 1) (Table 2).
Table I Past medical history

\begin{tabular}{ll}
\hline $\begin{array}{l}\text { General state of health } \\
\text { Childhood illnesses }\end{array}$ & middle illness \\
Immunizations & all ones according to the Cuban protocol \\
Surgeries & none \\
Injuries & none \\
Hospitalizations & none \\
Allergies & none \\
Exposure to the asbestos & It wasn't founded
\end{tabular}

Table 2 Family history

\begin{tabular}{ll}
\hline Immediate Relative & Illness \\
\hline Mother & Healthy \\
Father & Arterial hypertension \\
Siblings & None
\end{tabular}

BAAR spit and cultivation: (1) (2) (3) Code zero.

Bacteriological spit: (1) (2) (3) bacterial growth was not observed.

Mycological spit: (1) (2) (3) fungal growth was not observed

\section{Thoracic ultrasound and of soft parts}

Tumoral thickness of the parietal pleura in the whole right side with very scarce quantity of liquid, ganglionary chains, cervical, axillary and inguinal are explored, were observed several adenophaties of inflammatory aspect, at level axillary right two adenophaties of 2 and $2.5 \mathrm{~cm}$ are observed without mediastinum with pathological aspect.

\section{Simple CT scan of skull, thorax and abdomen}

\section{Skull: Not encephalic alterations for this study}

Lung asymmetry for hipodensity area of lung with tumoral aspect in half or inferior third of the right lung that impresses to obliterate for 
infiltration the bronchus of the right inferior lobe. This lung mass of lobulated contours and in some espiculated areas, in their inferior end it melts with the mediastinum. They also exist other lung nodules of sub-pleural localization that go from 7 to $15 \mathrm{~mm}$, also at pleural level exists thickness of the same one, of nodular aspect, where acquires its biggest thickness right anterobasal ending up measuring $52 \mathrm{~mm}$. Slight right pleural effusion, multiple adenophaties in conglomerate in the whole mediastinum from the region infraclavicular. Non alterations in the left lung. Elevation of the right hemidiafragm, not suprarenal lesion, not lesion ocupative of the hepatic space, don't injure of lumbar bone.

\section{Cytological study (needle biopsy)}

This study was indicated in first instance to try to explain the thickness of the pleura and it showed an extended constituted by numerous epithelial tumoral cells prepared in morulae and sheets, positive of Carcinoma of non-small cells. Possible Adenocarcinoma or Malignant Mesothelioma.

\section{Echocardiogram}

The patient has heart cavities of normal size, global and segmental contractibility of the left ventricle conserved in rest, non-masses, don't spill, competent valves, normal diastolic function, normal right cavities, LVEF (Left ventricle ejection fraction) $71 \%$. Normal Echocardiogram in rest.

\section{Biopsy of pleura and lung}

The biopsy of pleura of this patient showed an Epithelioid Mesotelioma with papillary areas. The Immunohistochemistry markers used to carry out this diagnosed were Citoqueratinas 5/6 (CK), Wilms tumor Antigen type 1 (WT-1) and Mesotelina which are positive. Calretinina and 7 (CK) were highly positive and Napsina A was negative.

\section{Discussion}

This type of malignant tumor is more frequent at level of the parietal pleura, toward inferior portions with a pattern of diffuse growth, it encapsulates the whole lung and it invades thoracic structures; clinically it is presented with pleural effusion recidivist and thoracic pain. ${ }^{11}$ In our patient the thoracic pain was the initial element that due to the character and the irradiation was interpreted as a somatic etiology. Clinical element that suggest a tumoral diagnosis were the duration and worsened of pain on the time. On physical examination the thoracic expansibility diminished in all right hemithorax and the presence of adenophaties with tumoral consistence in the same side to lend support this etiology (Table 3). In the other hands elements that questioned the diagnosis firstly were the mediastinal participation and the presence of bronchial infiltration (Figure 1) that is usually more frequent in the lymphoma and in the bronchogenic tumor respectively. Besides the patient's age. The quantity of the pleural effusion was always scarce. Imagenological elements to favour was the marked pleural thickness, the nodular pattern of the same one and the left displacement of the mediastinum (Figure 2). Humoral element that support the diagnosis were the anemia, thrombocytosis and decreased iron level (Table 4) characteristic of this type of process. Although a marker unique immunohistochemistry doesn't exist with the enough specificity to carry out the diagnosis of malignant mesothelioma, the common thing is to use a panel of markers. It should be considered that the pancitoqueratinas tints to most of the mesothelioma. For mesothelioma epithelioid the positive markers include the calretinina, Citoqueratinas (CK) 5/6, the nuclear Wilms tumor Antigen type 1 (WT-1) and the podoplanina (D2-40). For the adenocarcinoma are used the carcinoembrionary antigen, Ber-EP4, TTF-1 and napsina A, ${ }^{12}$ which confirmed the definitively diagnosis in this patient. In relation to the treatment, the radiotherapy and the chemotherapy have shown little influence on the survival are high the mortality and the surgical morbidity (near at the five and 50\%, respectively). The main objective of this it consists on palliating the main symptoms, the dysnea and the thoracic pain, it can include chemotherapy, radiotherapy and the surgical intervention (or both).$^{13}$ In this case we decided to begin treatment with Carboplatino $350 \mathrm{mg} / \mathrm{m}^{2} /$ day, Paclitaxel $175 \mathrm{mg} /$ $\mathrm{m}^{2}$ /day and Vinblastina $6 \mathrm{mg} / \mathrm{m}^{2} /$ day all regimens each 21 days. Because the combination of several chemotherapy including a Platino compound may result more effective than the monotherapy, ${ }^{14,15}$ being able to improve partially the symptomatology.

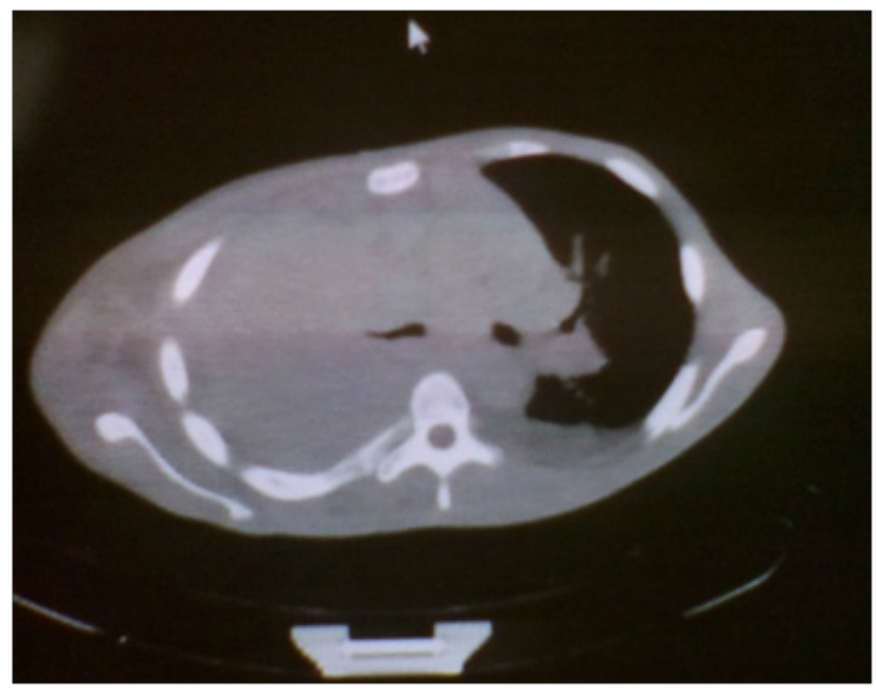

Figure I Simple CT Scan that show lung asymmetry for hipodensity area of lung with tumoral aspect that impresses to obliterate for infiltration the bronchus of the right inferior lobe.

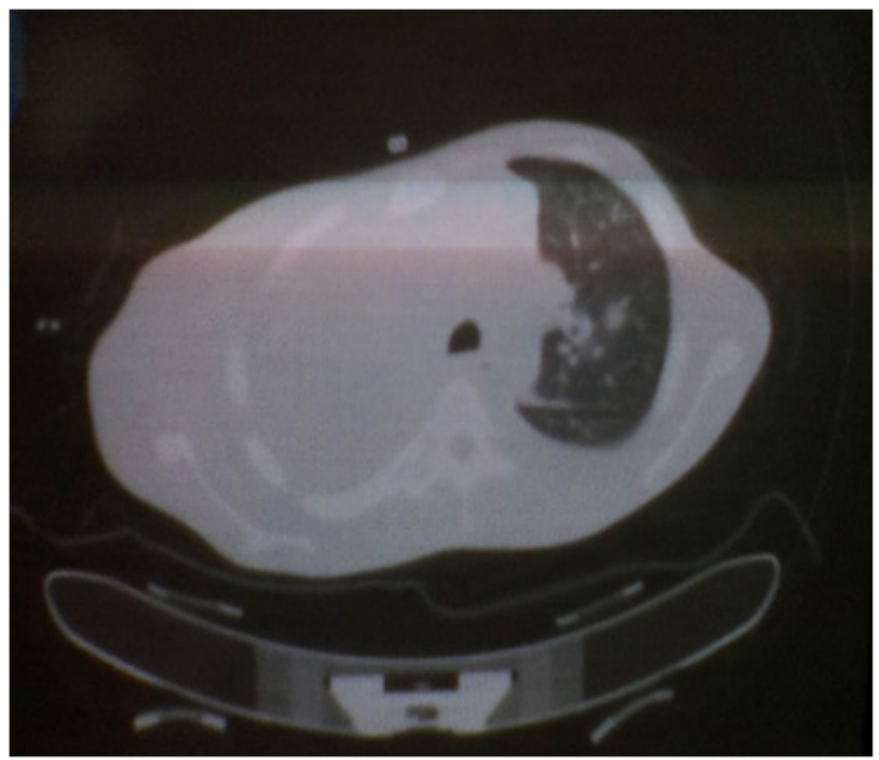

Figure 2 Simple CT Scan that show left mediastinal displacement. 
Table 3 Physical examination

\begin{tabular}{|c|c|}
\hline Systems & Positive findings \\
\hline Skin and Mucous & Widespread mucous cutaneous paleness. \\
\hline Respiratory & $\begin{array}{l}\text { Thoracic expandability diminished to expense of the right side, vocal vibrations diminished in two inferior thirds and abolished on } \\
\text { the right base. Vesicular murmur diminished in same localization and abolished on the base. Non crackles. Breathing frequency } 19 \\
\text { per minute. }\end{array}$ \\
\hline Cardiovascular & Rhythmic heart sound, not heart murmur, heart frequency 90 beat per minute. Blood Pressure $110 / 70 \mathrm{~mm} / \mathrm{Hg}$. \\
\hline Abdomen & Soft, depresible, not painful to the superficial, neither deep palpation, bowel sounds normal. \\
\hline Hemolifopoyetic & $\begin{array}{l}\text { Right axillary adenophaties, } 2-2.5 \mathrm{~cm} \text {, firm, of hard consistency, stuck to deep planes, in number of two; three more small of } \\
1-1.5 \mathrm{~cm} \text {, fibroelastics, lightly painful among } 3^{\text {rd }} \text { and } 5^{\text {th }} \text { intercostal space. }\end{array}$ \\
\hline
\end{tabular}

Table 4 Laboratory test

\begin{tabular}{|c|c|c|}
\hline Variable & On Admission & Reference range \\
\hline White-cell count & $11.8 \times 10^{9} \mathrm{~L}$ & $\left(5-10 \times 10^{9}\right) / L$ \\
\hline Neutrophils\% & 77.9 & $(53-65) \%$ \\
\hline Lymphocytes\% & 15.5 & $(15-40) \%$ \\
\hline Mid\% & 6.6 & $(5-10) \%$ \\
\hline Haemoglobin & $102 \mathrm{~g} / \mathrm{L}$ & $(|25-| 50) g / L$ \\
\hline Haematocrit\% & 32 & $(40-52) \%$ \\
\hline Mean corpuscular volume & $72.8 f / /$ & $(87-97) f / l$ \\
\hline Mean corpuscular haemoglobin & $23.1 \mathrm{pg}$ & $(27-37) p g$ \\
\hline Mean corpuscular hemoglobin level & $317 f / L$ & $(320-360) f / L$ \\
\hline Red-cell distribution width & $15.10 \%$ & $(11.5-14.5) \%$ \\
\hline Platelet count & $637 \times 10^{3}$ & $(150-350) \times 10^{3}$ \\
\hline Golbular sedimentation velocity & $40 \mathrm{~mm} / \mathrm{h}$ & $(87-97) \mathrm{mm} / \mathrm{h}$ \\
\hline Lactate dehydrogenase & $299 \mathrm{mmol} / \mathrm{L}$ & $(230-460) \mathrm{mmol} / \mathrm{L}$ \\
\hline Alanine amintransferase & $19 \mathrm{mmol} / \mathrm{L}$ & $(0-46) \mathrm{mmol} / \mathrm{L}$ \\
\hline Aspartate aminotransferase & $23 \mathrm{mmol} / \mathrm{L}$ & $(0-49) \mathrm{mmol} / \mathrm{L}$ \\
\hline Ganma glutamil transpeptidasa & $61 \mathrm{mmol} / \mathrm{L}$ & $(5-45) \mathrm{mmol} / \mathrm{L}$ \\
\hline Alkaline phosphatase & $318 \mathrm{mmol} / \mathrm{L}$ & $(100-290) \mathrm{mmol} / \mathrm{L}$ \\
\hline Amilasa & $48 \mathrm{mmol} / \mathrm{L}$ & $(0-90) \mathrm{mmol} / \mathrm{L}$ \\
\hline Glucose & $3.89 \mathrm{mmol} / \mathrm{L}$ & $(4.20-6.1 \mathrm{I}) \mathrm{mmol} / \mathrm{L}$ \\
\hline Cholesterol & $3.48 \mathrm{mmol} / \mathrm{L}$ & $(3.87-6.20) \mathrm{mmol} / \mathrm{L}$ \\
\hline Triglycerides & $0.62 \mathrm{mmol} / \mathrm{L}$ & $(0.46-\mathrm{I} .88) \mathrm{mmol} / \mathrm{L}$ \\
\hline Uric Acid. & $184 \mathrm{mmol} / \mathrm{L}$ & $(155-428) \mathrm{mmol} / \mathrm{L}$ \\
\hline Total proteins & $81.5 \mathrm{~g} / \mathrm{L}$ & $(60-80) g / L$ \\
\hline Albumin & $46 g / /$ & $(38-54) g / L$ \\
\hline Total bilirubin & $8.17 \mathrm{mmol} / \mathrm{L}$ & $(0-21) \mathrm{mmol} / \mathrm{L}$ \\
\hline Seric iron & $3.40 \mathrm{mmol} / \mathrm{L}$ & $(8.35-30) \mathrm{mmol} / \mathrm{L}$ \\
\hline Creatinine & $98.2 \mathrm{mmol} / \mathrm{L}$ & $(47.6-1 \mid 3.4) \mathrm{mmol} / \mathrm{L}$ \\
\hline Calcium & $2.30 \mathrm{mg} / \mathrm{dl}$ & $(2.02-2.60) \mathrm{mg} / \mathrm{dl}$ \\
\hline Phosphorus & $1.22 \mathrm{mg} / \mathrm{dl}$ & $(\mathrm{I}-\mathrm{I} .50) \mathrm{mg} / \mathrm{dl}$ \\
\hline
\end{tabular}




\section{Conclusion}

The final diagnosis was made by the combination of clinical, imagenological and histological finding, the last one essential to confirm the diagnostic hypothesis in relation with the range of histological possibilities. His evolution was stable for the next 4 months after that he died of suddenly episode of pulmonary embolism.

\section{Acknowledgments}

None.

\section{Conflicts of interest}

The authors declare there is no conflicts of interest.

\section{References}

1. Wagner JC, Sleggs CA, Marchand P. Diffuse pleural mesothelioma and asbestos exposure in the North Western Cape Province. $\mathrm{Br}$ J Ind Med. $1960 ; 17: 260-271$

2. Raúl Barrera R, Jorge Chavarría G, Jorge Morales F. Malignant mesothelioma: Clinical and pathological features from 247 cases. Rev Chil Enf Respir. 2010;26(3):134-140.

3. Enrique Gea-Izquierdo. Pleural mesothelioma and asbestos exposure in Spain. Revista Cubana de Investigaciones Biomédica. 2016;35(1):1-17.

4. Ferri FF. Mesothelioma, Malignant. Ferri's Clinical Advisor. 9th ed. USA: Elsevier; 2016:791-792.

5. Rodríguez Panadero F. Enfermedades de la Pleura. In: Farreras Valenti P, Rozman C, Cardellach López F, editors. Tratado de Medicina Interna.18th ed. Barcelona España: Elsevier; 2016:749-751.
6. Butnor KJ, Sporn TA, Hammar SP, et al. Well-differentiated papillary mesothelioma. Am J Surg Pathol. 2001;25(10):1304-1309.

7. Ordóñez NG. Epithelial mesothelioma with deciduoid features: report of four cases. Am J Surg Pathol. 2000;24(6):816-823.

8. Lin-Chu M, Lee YJ, Ho MY. Malignant mesothelioma in infancy. Arch Pathol Lab Meth. 1989;113(4):409-410.

9. Ettinger DS, Akerley W, Borghaei $\mathrm{H}$, et al. Malignant pleural mesothelioma. J Natl Compr Canc Netw. 2012;10(1):26-41.

10. Fernández Francés J. Cáncer de pleura. Mesotelioma. Medicine. 2014;11(67):3995-4000.

11. García Atienza EM, Val Jiménez CL, Navarro Ruiz S, et al. Mesotelioma pleural maligno. Med Paliat. 2015;24(1):47-50.

12. Neumann V, Löseke S, Nowak D, et al. Malignant pleural mesothelioma. Dtsch Arztebl Int. 2013;110(8):319-326.

13. Rodríguez PF. Aspectos diagnósticos y terapéuticos en el mesotelioma pleural maligno. Rev Med Clin Condes. 2015;26(3):325-337.

14. Fennell DA, Gaudino G, O'Byrne KJ, et al. Advances in the systemic therapy of malignant pleural mesothelioma. Nat Clin Pract Oncol. 2008;5(3):136-147.

15. Nowak AK. Chemotherapy for malignant pleural mesothelioma: A review of current management and a look to the future. Ann Cardiothorac Surg. 2012;1(4):508-515. 